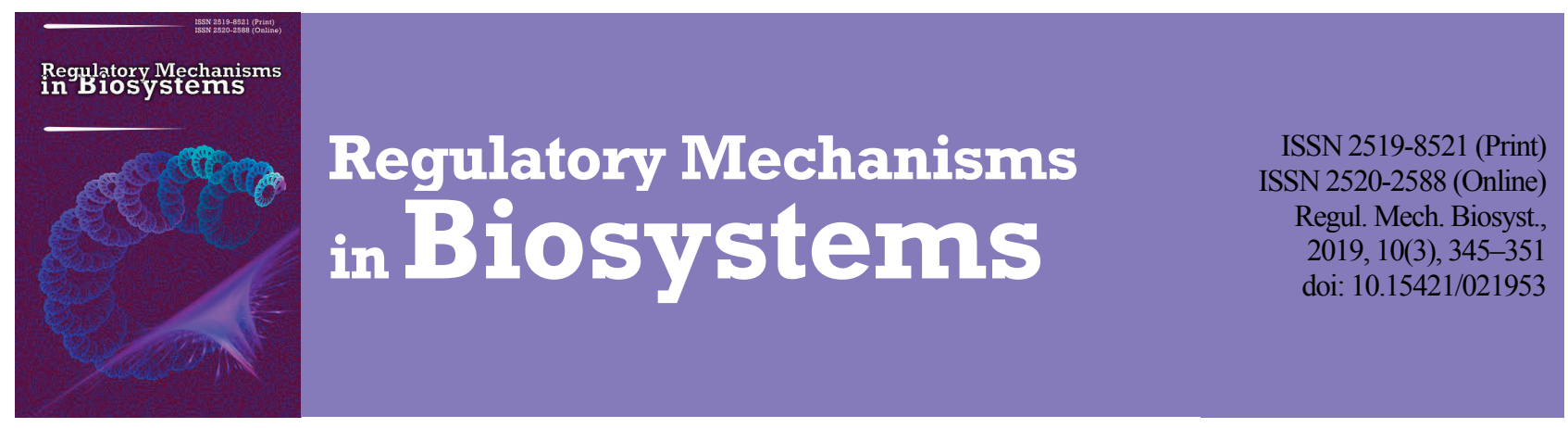

\title{
Application of correlation analysis in cytology: Opportunities to study specific activity of follicular thyrocytes
}

\author{
O. I. Ryabukha*, I. M. Dronyuk** \\ *Lviv Medical Institute, Lviv, Ukraine \\ **Lviv Polytechnic National University, Lviv, Ukraine
}

Article info

Received 27.07.2019

Received in revised form

22.08.2019

Accepted 25.08.2019

Lviv Medical Institute,

Polishchuka st., 76

Lviv, 79018, Ukraine

Tel.: +38-098-449-33-18

E-mail: oriabu-

ha@ukrnet

Lviv Polytechnic

National University,

S. Bandera st., 12 ,

Lviv, 79013, Ukraine

\author{
Ryabukha, O. I., \& Dronyuk, I. M. (2019). Application of correlation analysis in cytology: Opportunities to study specific activity of \\ follicular thyrocytes. Regulatory Mechanisms in Biosystems, 10(3), 345-351. doi:10.15421/021953
}

The task of biomedical diagnostics is to determine the dependence of the conclusion/diagnosis on the sets of parameters that characterize the state of the biosystem/patient. The performed analytical review of modern scientific literature permitted us to determine that Bayesian, regression and correlation analyzes and logical programming are most often used for biomedical diagnostics purposes. At the same time, their informativeness can only be realized for the solution of those diagnostic tasks in which quantitative parameters are analyzed. Qualitative and binary information provides an opportunity to find out more about features of the biosystem's state. However, its use is limited, since the results obtained are presented in words (that is, in a linguistic form) that cannot be processed by means of traditional (digital) mathematical analysis. The objective of this work was determining the capabilities of the mathematical apparatus to deepen the study of hormonopoiesis in the thyroid gland. The object of the study was electron micrographs of ultrathin tissue sections, its subject was the features of correlations between ultrastructural cell elements which carry out the processes of synthesis and secretion in follicular thyrocytes. In the context of studying the features of synthetic and secretory activity of follicular thyrocytes of the thyroid glands in white male rats, it was shown that the objectification of non-numerical information about the state of cells allows us to use linguistic information about changes in their morphofunctional state. Implementation of correlation analysis for studying the relationships and interdependencies between organelles which implement synthesis and secretion of the hormonal product in the main structural unit of the thyroid gland - follicular thyrocyte - allows us to determine, study, analyze and generalize peculiarities of both changes in individual ultrastructures and their functional complexes (clusters) in response to the actions of various factors and to trace the interdependencies and mutual interactions existing between them, as well as to deepen the idea of the intimate mechanism features of the specific directions of follicular thyrocyte activity, which substantially expands the research platform in cytophysiology and cytomorphology.

Keywords: thyroid gland; cytophysiology; correlation portrait; expert systems.

\section{Introduction}

Modern biology and medicine are passing into a new phase of their development, which implies wider involvement of mathematical approaches to solving problems in certain sections of these disciplines (Murray, 2003; Tiwari, 2012; Amigó \& Small, 2017). Determination of the fields of biomedical research and objectivizing their results implies the application of various mathematical analysis methods.

This need has arisen due to the fact that traditional methods of research used in medicine and biology no longer satisfy the theoretical and practical demands of researchers, since they are based on the opposite conceptual principles: the use of either quantitative data about the investigated object obtained from its measurements, or qualitative information that describes the status of a given object of research in the words of the language used. At the same time, the quantitative definitions, despite their objectivity, do not allow us to determine and analyze all the nuances of the biological system's state, which can be an organism/tissue/cell, whereas the qualitative information that can mark the slightest changes in the state of the system under examination in various positive and negative influences is not subject to calculation. This makes it subjective and does not permit comparisons, evidence based conclusions, analyses and generalizations.

The task of biomedical diagnostics is to determine the dependence of the diagnosis on a plurality of parameters of the studied system's state, which can be quantitative, qualitative or binary. The basic mathe- matical methods used to solve the set tasks are Bayesian, regression and correlation analyzes, logical programming and the principle of phase interval; diagnosis on the principles of fuzzy logic is promising.

Bayesian analysis has been implemented in various research areas (Meeus et al., 2010; Rietbergen et al., 2011; van de Schoot et al., 2014). In particular, in biomedical diagnostics, if $p\left(d_{j}\right)$ is an a priori probability of diagnosis $d_{j}, j=\overline{1, m}$, then $P\left(X^{*} / d_{j}\right)$ will be conditional (a posteriori) probability of diagnosis $d_{j}$ occurrence in the patient with the state parameters $X^{*}=\left(x_{1}^{*}, x_{2}^{*}, \ldots, x_{n}^{*}\right)$. After calculating the a posteriori probabilities of all possible diagnoses according to the Bayes' theorem, from their totality the one for which the probability is the greatest is selected:

$$
P\left(d_{j} / X^{*}\right)=\frac{p\left(d_{j}\right) \cdot P\left(X^{*} / d_{j}\right)}{\sum_{j=1}^{n} p\left(d_{j}\right) \cdot P\left(X^{*} / d_{j}\right)} .
$$

The diagnosis process based on the Bayesian approach is now widely used in biological research to work with known quantitative information (Aguilera et al., 2011; Tighe et al., 2013). At the same time, in medical diagnostics, its use has certain limitations, because it requires assuming that each disease is characterized by a pathognomonic complex of symptoms. Statistical information, which is a necessary ground for the method's application, in practical medicine is usually limited, and the introduction of new data into the model is associated with the need to recalculate all probabilities. Despite the fact that collecting, processing and storage of information important for diagnosis requires a certain time and effort, the diagnostic conclusion obtained on its basis is 
sometimes difficult to justify. When applying regression analysis, the following linear regression equation is used:

$$
q=a_{0}+a_{1} x_{1}+a_{2} x_{2}+\ldots+a_{n} x_{n},
$$

where $q$ depends on the vector of the input parameters $X=\left(x_{1}, x_{2}, \ldots\right.$, $x_{n}$ ), whereas $a_{0}, a_{1}, a_{2}, \ldots, a_{n}$, are unknown parameters which are determined by the least squares method. This type of analysis is also designed for work with biological information to be computed (van Someren et al., 2006; Lu, 2016). The use of the regression analysis method for the needs of medical diagnostics also has a number of limitations. In particular, it only permits performing the diagnostic and prediction tasks in which the studied parameters are quantified (Whitley \& Ball, 2002; Bewick et al., 2003; Courvoisier et al., 2011). In addition, the method under discussion is characterized by insufficient reproducibility of the research results and by the need for working through these results in large volumes, which is not always expedient under the conditions of a given experiment and clinic.

The task of the correlation analysis method is to determine correlations between the studied parameters, the nature and pronouncement of which are established by the pair correlation coefficient (Akoglu, 2018; Schober et al., 2018; Uurtio et al., 2018). Prolonged use of the method facilitated the data accumulation for studying various biomedical processes (Miot, 2017, 2018; Yadav, 2018) at their multiple levels (Rossi et al., 2015; Maranzatto et al., 2016; Kim et al., 2017), which resulted in the development of tools to facilitate visualization, analysis and interpretation of the information obtained (Mutwil et al., 2010; Batushansky et al., 2016). However, the method is not intended to work with qualitative or binary data on the state of a studied biosystem.

In expert systems, the method of formal description is quite widely used, for the implementation of which the language of logical programming Prolog is used (Talbot, 2018). This language is suitable for searching a chain of rules coming from the factors $\left(x_{i}^{*}\right)$ to the goal $\left(d_{j}^{*}\right)$ or from the goal $\left(d_{j}^{*}\right)$ to the factors $\left(x_{i}^{*}\right)$ that are selected from the database. In medicine, this method frequently permits one not only to diagnose, but also to substantiate the reasons for the decision taken to a large extent. However, Prolog solves the problem by the exhaustive search method, which limits its possibilities for infinite output sets (Bessmertnyy et al., 2019); in the case where knowledge has a probabilistic nature, the method of logical conclusion cannot be applied.

The phase interval principle (Plashchevaya et al., 2014) implies determining the diagnosis of a patient by calculating the distance between two points in the Euclidean space, each coordinate $x_{i}(i=\overline{1, n})$ of which indicates one of the patient's state parameters, and points $x_{1}, x_{2}, \ldots, x_{n}$ correspond to a certain diagnosis $d_{j}, j=\overline{1, m}$. The method does not require accumulation of significant statistical material and great efforts for its processing, but is only limited by quantitative and binary parameters of the studied biological object's state.

The theory of fuzzy sets (Gupta, 2011) is a means of formalizing the uncertainties that occur in the biological system (Torres \& Nieto, 2006). It is used as a means of solving research problems that arise in the study of a living organism in biomedical research (Patel et al., 2013; Gürsel, 2016). When carrying out biomedical diagnostics on the principles of fuzzy logic (Dev et al., 2015), relatively simple mathematical methods are used. In particular, the notion of membership function and the greatest and least expression of any attribute (max-y and min- $y$ ), as well as certain scientific and methodological principles, are used.

According to the principle of linguistic diagnosis and the patient's state parameters, the diagnosis and the patient's state parameters are linguistic variables. The principle of verbality of diagnostic data implies the existence of cause-effect relationships between the parameters of the biological system's state (cause) and the diagnosis (effect), which are initially described in terms of the language used, and then formalized as a total of fuzzy logical statements.

Formalizing the diagnostic process on the basis of fuzzy logic implies determining the diagnosis $d$ through the input parameters (variables) $x_{1}, x_{2}, \ldots, x_{n}$, which characterize the patient's state. Then:

$$
d=f_{d}\left(x_{1}, x_{2}, \ldots, x_{n}\right)
$$

where $f_{d}$ is some function that determines the relationship between the variables $x_{i}, i=\overline{1, n}$ and $d$.
Variables $x_{1} \div x_{n}$ and function $d$ can be quantitative, qualitative, or expressed by means of special scales, for example, in the point scoring system. This permits the qualitative colouration of the state, which significantly extends the possibilities of determining the correct diagnosis, but requires the special training of the researcher.

The need for formalization of qualitative and binary information about the state of a biological object is urgent in cytology, which traditionally applies such a heuristic method as linguistic description, which makes the completeness of the received information about the object and its interpretation dependent on the qualification of the researcher and makes the final conclusion subjective (Ryabukha, 2018a). In its turn, traditional morphometry, which, when processing quantitative parameters, uses such a component of a mathematical apparatus as mathematical statistics, despite the possibility of comparisons, does not have at its disposal means that permit complete implementation of expanded analysis and generalization, which is very important for establishing the regularities of cell activity and clarification of features of their changes under the influence of various factors.

Our previous studies (Ryabukha, 2018b, 2019) have shown that a promising field of implementing mathematical technologies in the process of diagnosis in cytomorphology and cytophysiology is a package of specific mathematical methods, any of which is the basis for the next step. In this case, the diagnostic process will be integrated, will proceed in several stages and permit the object under study to be characterized in a multifaceted manner. The basic requirements for choosing the mathematical methods should be the informative value of the results obtained, the possibility of their subsequent mathematical transformation and ease of use. The combination of the phase interval principle and the method of correlation analysis, carried out on the basis of verbality in determining the state of the studied object, correspond to the requirements stated above. This allows further interpretation of the traced correlations and their interdependence in terms of cytophysiology (Ryabukha \& Dronyuk, 2018).

The objective of the study was use of the mathematical apparatus capabilities adapted to studying the activity of the cell as a biological system for the in-depth study of various courses of hormonopoiesis in the thyroid gland.

\section{Materials and methods}

The study was carried out on the example of analysis of correlation portraits of synthetic and secretory follicular thyrocytes activity. Its object was electron-diffraction patterns made according to generally accepted techniques of ultrathin $(4-6 \mu \mathrm{m})$ sections of thyroid gland tissues obtained from white outbred rat males, of the initial weight of 140-160 g, which were kept on an iodine-deficient isocaloric starch-casein diet for 30 days. To correct the alimentary hypothyroidism, the animals consumed $50 \mu \mathrm{g}$ per $\mathrm{kg}$ body weight of organic and inorganic iodine. Organic iodine was introduced into the diet with iodine-protein preparation derived from the red Black Sea algae Phyllophora nervosa (Phyllophora crispa), inorganic iodine - from the potassium iodide solution. The object of study was the correlation features between ultrastructural elements which implement the processes of synthesis and secretion in follicular thyrocytes. The totality of organelles-implementers in each field of the thyrocyte activity (clusters of synthetic and secretory potentials) are presented respectively in Table 1 and 2 (Ryabukha, 2018b; Ryabukha \& Dronyuk, 2018; Ryabukha, 2019).

Determination of the state of ultrastructures of follicular thyrocytes was based on visual examination of electron micrographs. Its results were described in words. The obtained visual picture was compared to the results in the two diametrically opposite controls, i.e., according to the principle of the phase interval method, the state in norm and that in uncorrected pathology.

The state and number of ultrastructures belonging to the studied cluster were ranked within the range of "a little-moderately (norm) - a lot". According to a specially designed scale, the results were assessed in points, taking into account the expression of the sign under study: 0 points - no sign, 1 - sign slightly expressed, 2 - sign is expressed moderately, 3 - sign is expressed markedly, 4 points - sign is expressed to 
the maximum. The obtained digital indices were averaged and used for correlation analysis, applying the Pearson pair correlation coefficient, which is calculated using the formula:

$$
r_{x y}=\frac{\sum_{i=1}^{i=n}\left(x_{i}-\bar{x}\right)\left(y_{i}-\bar{y}\right)}{\sqrt{\sum_{i=1}^{i=n}\left(x_{i}-\bar{x}\right)^{2} \sum_{i=1}^{i=n}\left(y_{i}-\bar{y}\right)^{2}}}
$$

where $r_{x y}$ - coefficient of pair correlation between the indices $x$ and $y$; $x_{i}$ - the $x$ index value in $i$-observation; $y_{i}$ - the $y$ index value in $i$-observation; $n$-number of observations, $\bar{x}$-mean value of the $x$ index for $n$ observations performed; $\bar{y}$ - mean value of the $y$ index for $n$ observations performed.

\section{Table 1}

Synthetic activity components (cluster of synthetic potentials) of follicular thyrocytes

\begin{tabular}{lccc}
\hline $\begin{array}{c}\text { Ultrastructural } \\
\text { element }\end{array}$ & $\begin{array}{c}\text { Studied feature } \\
\text { of the ultrastruc- } \\
\text { tural element }\end{array}$ & $\begin{array}{c}\text { Status of the studied } \\
\text { ultrastructural ele- } \\
\text { ment feature }\end{array}$ & $\begin{array}{c}\text { Symbol legend of the } \\
\text { studied ultrastructural } \\
\text { element feature }\end{array}$ \\
\hline Cytoplasm & electron density & $\begin{array}{c}\text { insignificant } \\
\text { moderate } \\
\text { significant }\end{array}$ & $\mathrm{B}_{1}$ \\
& constricted & $\mathrm{B}_{2}$ \\
Rough & structure & normal & $\mathrm{B}_{3}$ \\
endoplasmic & & increased & $\mathrm{J}_{2}$ \\
reticulum & number of mem- & reduced & $\mathrm{J}_{3}$ \\
(rough ER) & brane bound & moderate & $\mathrm{J}_{4}$ \\
& ribosomes & increased & $\mathrm{J}_{5}$ \\
Free ribosomes & & reduced & $\mathrm{J}_{6}$ \\
and polysomes & number & moderate & $\mathrm{K}_{1}$ \\
& & increased & $\mathrm{K}_{2}$ \\
Golgi & & constricted & $\mathrm{K}_{3}$ \\
apparatus & structure & normal & $\mathrm{L}_{1}$ \\
\hline
\end{tabular}

Table 2

Secretory activity components (cluster of secretory potentials) of follicular thyrocytes

\begin{tabular}{|c|c|c|c|}
\hline $\begin{array}{c}\text { Ultrastructural } \\
\text { element }\end{array}$ & $\begin{array}{l}\text { The studied feature } \\
\text { of the ultrastruc- } \\
\text { tural element }\end{array}$ & $\begin{array}{l}\text { Status of the studied } \\
\text { ultrastructural ele- } \\
\text { ment feature }\end{array}$ & $\begin{array}{l}\text { Symbol legend } \\
\text { of the studied } \\
\text { ultrastructural } \\
\text { element feature }\end{array}$ \\
\hline \multirow{4}{*}{$\begin{array}{l}\text { Intrafollicular } \\
\text { colloid }\end{array}$} & \multirow{4}{*}{$\begin{array}{l}\text { electron } \\
\text { density }\end{array}$} & insignificant & $\mathrm{E}_{1}$ \\
\hline & & moderate & $\mathrm{E}_{2}$ \\
\hline & & significant & $\mathrm{E}_{3}$ \\
\hline & & insignificant & $\mathrm{H}_{1}$ \\
\hline \multirow{9}{*}{$\begin{array}{l}\text { Microvilli } \\
\text { of the apical } \\
\text { plasma } \\
\text { membrane }\end{array}$} & \multirow[t]{2}{*}{ quantity } & moderate & $\mathrm{H}_{2}$ \\
\hline & & significant & $\mathrm{H}_{3}$ \\
\hline & \multirow{4}{*}{$\begin{array}{l}\text { density } \\
\text { of location, } \\
\text { length }\end{array}$} & insignificant & $\mathrm{H}_{4}$ \\
\hline & & moderate & $\mathrm{H}_{5}$ \\
\hline & & significant & $\mathrm{H}_{6}$ \\
\hline & & insignificant & $\mathrm{G}_{1}$ \\
\hline & \multirow[t]{3}{*}{ quantity } & moderate & $\mathrm{G}_{2}$ \\
\hline & & significant & $\mathrm{G}_{3}$ \\
\hline & & small & $\mathrm{G}_{4}$ \\
\hline \multirow[t]{9}{*}{ Lysosomes } & \multirow[t]{2}{*}{ size } & medium & $\mathrm{G}_{5}$ \\
\hline & & big & $\mathrm{G}_{6}$ \\
\hline & \multirow{3}{*}{$\begin{array}{l}\text { electron } \\
\text { density }\end{array}$} & insignificant & $\mathrm{G}_{7}$ \\
\hline & & moderate & $\mathrm{G}_{8}$ \\
\hline & & significant & $\mathrm{G}_{9}$ \\
\hline & & insignificant & $\mathrm{M}_{1}$ \\
\hline & quantity & moderate & $\mathrm{M}_{2}$ \\
\hline & & significant & $\mathrm{M}_{3}$ \\
\hline & & insignificant & $\mathrm{M}_{4}$ \\
\hline \multirow{6}{*}{$\begin{array}{l}\text { Secretory } \\
\text { granules }\end{array}$} & electron & moderate & $\mathrm{M}_{5}$ \\
\hline & density & significant & $\mathrm{M}_{6}$ \\
\hline & allocation & apical pole & $\mathrm{M}_{7}$ \\
\hline & allocation & along the whole cell & $\mathrm{M}_{8}$ \\
\hline & topographic & absent & $\mathrm{M}_{9}$ \\
\hline & $\begin{array}{c}\text { connection } \\
\text { with lysosomes }\end{array}$ & present & $\mathrm{M}_{10}$ \\
\hline
\end{tabular}

Analysis of correlations was carried out taking into account their strength, quantity and communication sign. The positive value of the pair correlation coefficient $\left(r_{x y}=1.0\right)$ indicated the same direction of change in the studied signs, the negative $\left(r_{x y}=-1.0\right)$ - that the increase of one index is accompanied by a decrease in the associated index. In the structural organization of the correlations between the indices, the most significant were considered very strong and strong connections, which on the Chaddock scale of correlation were respectively within the range of $0.91<r_{x y}<1.0$ and $0.71<r_{x y}<0.9$; connections of lesser strength were taken into account in cases of absence or insufficient number of very strong and strong connections.

Interpretation of the developed correlation portraits was based on views of the thyrocytes' hormonopoiesis features (Barrett, 2016), taking into account the functional significance of organelles (Caplan, 2016), the strength and sign of correlations traced between them. The traced correlation connections were illustrated by the graphic construction of correlation portraits (Ryabukha, 2018a).

The processing of the results was performed using the following software: for the digital parameters - StatSoft Statistica v6.0 package, for correlation tables and portraits - Microsoft Office 2010 package MS Excel spreadsheet and MS Word (Microsoft Graph), respectively.

\section{Results}

The presence of correlation connections between ultrastructural elements of the synthetic activity of the thyroid glands' follicular thyrocytes in rats under the model conditions of correcting the alimentary iodine deficiency with iodine of different chemical nature, their strength and direction are presented in Table 3 and 4.

\section{Table 3}

Correlations between the constituent elements of the synthetic direction portrait of follicular thyrocytes' activity in the thyroid glands of white male rats who received $50 \mu \mathrm{g}$ of organic iodine in the model conditions of iodine deficiency in the diet

\begin{tabular}{|c|c|c|}
\hline \multicolumn{2}{|c|}{ Interdependent ultrastructural elements of the portrait } & \multirow[b]{2}{*}{$\begin{array}{c}\text { Correlation } \\
\text { connection } \\
\text { (r) }\end{array}$} \\
\hline $\begin{array}{l}\text { characteristics } \\
\text { of the studied ultrastructural elements }\end{array}$ & $\begin{array}{c}\text { ultrastructural } \\
\text { elements features } \\
\text { legends }\end{array}$ & \\
\hline $\begin{array}{l}\text { Low electron density of cytoplasm-moderate } \\
\text { electron density of cytoplasm }\end{array}$ & $\mathrm{B}_{1}-\mathrm{B}_{2}$ & -0.801 \\
\hline $\begin{array}{l}\text { Low electron density of cytoplasm-moderate } \\
\text { number of membrane bound ribosomes }\end{array}$ & $\mathrm{B}_{1}-\mathrm{J}_{5}$ & 0.791 \\
\hline $\begin{array}{l}\text { Moderate electron density of cytoplasm - mod- } \\
\text { erate number of membrane bound ribosomes }\end{array}$ & $\mathrm{B}_{2}-\mathrm{J}_{5}$ & -0.845 \\
\hline $\begin{array}{l}\text { Moderate electron density of cytoplasm - in- } \\
\text { creased number of ribosomes in cytoplasm }\end{array}$ & $\mathrm{B}_{2}-\mathrm{K}_{3}$ & 0.786 \\
\hline $\begin{array}{l}\text { Normal structure of rough ER - normal structure } \\
\text { of Golgi apparatus }\end{array}$ & $\mathrm{J}_{2}-\mathrm{L}_{2}$ & 1.000 \\
\hline $\begin{array}{l}\text { Moderate number of membrane bound ribosomes- } \\
\text { increased number of ribosomes in cytoplasm }\end{array}$ & $\mathrm{J}_{5}-\mathrm{K}_{3}$ & -0.845 \\
\hline $\begin{array}{l}\text { Increased number of membrane bound ribosomes- } \\
\text { moderate number of ribosomes in cytoplasm }\end{array}$ & $\mathrm{J}_{6}-\mathrm{K}_{2}$ & 1.000 \\
\hline
\end{tabular}

\section{Table 4}

Correlations between the constituent elements of the synthetic direction portrait of follicular thyrocytes' activity in the thyroid glands of white male rats who received $50 \mu \mathrm{g}$ of inorganic iodine in the model conditions of iodine deficiency in the diet

\begin{tabular}{|c|c|c|}
\hline \multicolumn{2}{|c|}{ Interdependent ultrastructural elements of the portrait } & \multirow[b]{2}{*}{$\begin{array}{l}\text { Correlation } \\
\text { connection, } \\
\text { (r) }\end{array}$} \\
\hline $\begin{array}{l}\text { characteristics } \\
\text { of the studied ultrastructural elements }\end{array}$ & $\begin{array}{c}\text { ultrastructural } \\
\text { elements features } \\
\text { legends }\end{array}$ & \\
\hline 1 & 2 & 3 \\
\hline $\begin{array}{l}\text { Low electron density of cytoplasm - reduced } \\
\text { number of membrane bound ribosomes }\end{array}$ & $\mathrm{B}_{1}-\mathrm{J}_{4}$ & -0.612 \\
\hline $\begin{array}{l}\text { Low electron density of cytoplasm - moderate } \\
\text { number of ribosomes in cytoplasm }\end{array}$ & $\mathrm{B}_{1}-\mathrm{K}_{2}$ & -0.612 \\
\hline $\begin{array}{l}\text { Low electron density of cytoplasm - normal } \\
\text { structure of Golgi apparatus }\end{array}$ & $\mathrm{B}_{1}-\mathrm{L}_{2}$ & 0.645 \\
\hline $\begin{array}{l}\text { Moderate electron density of cytoplasm - normal } \\
\text { structure of rough ER }\end{array}$ & $\mathrm{B}_{2}-\mathrm{J}_{2}$ & 1.000 \\
\hline $\begin{array}{l}\text { Moderate electron density of cytoplasm - } \\
\text { expanded structure of rough ER }\end{array}$ & $\mathrm{B}_{2}-\mathrm{J}_{3}$ & -0.612 \\
\hline
\end{tabular}




\begin{tabular}{lcc}
\hline \multicolumn{1}{c}{1} & 2 & 3 \\
\hline $\begin{array}{l}\text { Moderate electron density of cytoplasm- } \\
\text { expanded structure of Golgi apparatus }\end{array}$ & $\mathrm{B}_{2}-\mathrm{L}_{3}$ & 1.000 \\
$\begin{array}{l}\text { Normal structure of rough ER - expanded } \\
\text { structure of rough ER }\end{array}$ & $\mathrm{J}_{2}-\mathrm{J}_{3}$ & -0.612 \\
$\begin{array}{l}\text { Normal structure of rough ER - expanded } \\
\text { structure of Golgi apparatus }\end{array}$ & $\mathrm{J}_{2}-\mathrm{L}_{3}$ & 1.000 \\
$\begin{array}{l}\text { Expanded structure of rough ER - normal } \\
\text { structure of Golgi apparatus }\end{array}$ & $\mathrm{J}_{3}-\mathrm{L}_{2}$ & 0.791 \\
$\begin{array}{l}\text { Expanded structure of rough ER - expanded } \\
\text { structure of Golgi apparatus }\end{array}$ & $\mathrm{J}_{3}-\mathrm{L}_{3}$ & -0.612 \\
$\begin{array}{l}\text { Reduced number of membrane bound ribosomes - } \\
\text { moderate number of ribosomes in cytoplasm }\end{array}$ & $\mathrm{J}_{4}-\mathrm{K}_{2}$ & 1.000 \\
$\begin{array}{l}\text { Reduced number of membrane bound ribosomes- } \\
\text { normal structure of Golgi apparatus }\end{array}$ & $\mathrm{J}_{4}-\mathrm{L}_{2}$ & -0.791 \\
$\begin{array}{l}\text { Moderate number of membrane bound ribosomes }- \\
\text { reduced number of ribosomes in cytoplasm }\end{array}$ & $\mathrm{J}_{5}-\mathrm{K}_{1}$ & 1.000 \\
$\begin{array}{l}\text { Moderate number of ribosomes in cytoplasm - } \\
\text { normal structure of Golgi apparatus }\end{array}$ & $\mathrm{K}_{2}-\mathrm{L}_{2}$ & -0.791 \\
$\begin{array}{l}\text { Normal structure of Golgi apparatus - expanded } \\
\text { structure of Golgi apparatus }\end{array}$ & $\mathrm{L}_{2}-\mathrm{L}_{3}$ & -0.645 \\
\hline
\end{tabular}

The traced correlations were visualized by the construction of correlation portraits (Fig. 1).

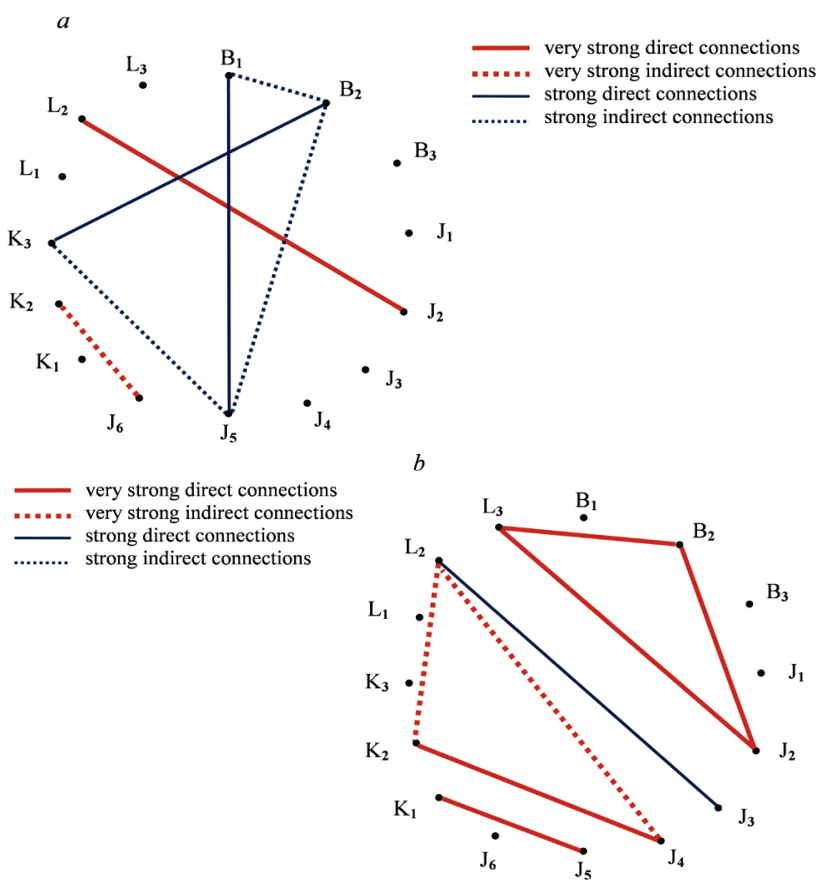

Fig. 1. Graphic representation of the structure of the synthetic direction correlation portraits of follicular thyrocyte activity in the thyroid glands of white male rats who received $50 \mu \mathrm{g}$ of organic $(a)$ and inorganic $(b)$ iodine of chemical nature under the model conditions of iodine deficiency in the diet (Ryabukha, 2018b)

Correlations between ultrastructural implementers of the secretory follicular thyrocytes' activity are presented in Table 5 and 6 .

Table 5

Correlations between the constituent elements of the secretory direction portrait of follicular thyrocytes' activity in the thyroid glands of white male rats who received $50 \mu \mathrm{g}$ of organic iodine in the model conditions of iodine deficiency in the diet

\begin{tabular}{|c|c|c|}
\hline \multicolumn{2}{|c|}{ Interdependent ultrastructural elements of the portrait } & \multirow[b]{2}{*}{$\begin{array}{c}\text { Correlation } \\
\text { connection } \\
\text { (r) }\end{array}$} \\
\hline Characteristics of the studied ultrastructural elements & $\begin{array}{l}\text { Ultrastructural } \\
\text { elements fea- } \\
\text { tures legends }\end{array}$ & \\
\hline 1 & 2 & 3 \\
\hline $\begin{array}{l}\text { Moderate electron density of intrafollicular colloid- } \\
\text { moderate number of lysosomes }\end{array}$ & $\mathrm{E}_{2}-\mathrm{G}_{2}$ & 1.000 \\
\hline $\begin{array}{l}\text { Moderate electron density of intrafollicular colloid- } \\
\text { moderate size of lysosomes }\end{array}$ & $\mathrm{E}_{2}-\mathrm{G}_{5}$ & 1.000 \\
\hline
\end{tabular}

\begin{tabular}{|c|c|c|}
\hline 1 & 2 & 3 \\
\hline $\begin{array}{l}\text { Moderate electron density of intrafollicular colloid- } \\
\text { moderate electron density of lysosomes }\end{array}$ & $\mathrm{E}_{2}-\mathrm{G}_{8}$ & 0.612 \\
\hline $\begin{array}{l}\text { Moderate electron density of intrafollicular colloid- } \\
\text { increased number of secretory granules }\end{array}$ & $\mathrm{E}_{2}-\mathrm{M}_{3}$ & 1.000 \\
\hline $\begin{array}{l}\text { Moderate electron density of intrafollicular colloid- } \\
\text { apical location of secretory granules }\end{array}$ & $\mathrm{E}_{2}-\mathrm{M}_{7}$ & 1.000 \\
\hline $\begin{array}{l}\text { Moderate electron density of intrafollicular colloid- } \\
\text { presence of secretory granules topographic connection } \\
\text { with lysosomes }\end{array}$ & $\mathrm{E}_{2}-\mathrm{M}_{10}$ & 1.000 \\
\hline $\begin{array}{l}\text { Moderate number of apical plasma membrane microvilli- } \\
\text { moderate electron density of secretory granules }\end{array}$ & $\mathrm{H}_{2}-\mathrm{H}_{5}$ & 1.000 \\
\hline $\begin{array}{l}\text { Moderate number of apical plasma membrane microvilli- } \\
\text { large size of lysosomes }\end{array}$ & $\mathrm{H}_{2}-\mathrm{G}_{6}$ & 0.612 \\
\hline $\begin{array}{l}\text { Moderate number of apical plasma membrane microvilli- } \\
\text { significant electron density of lysosomes }\end{array}$ & $\mathrm{H}_{2}-\mathrm{G}_{9}$ & 0.612 \\
\hline $\begin{array}{l}\text { Moderate number of apical plasma membrane microvilli- } \\
\text { moderate number of secretory granules }\end{array}$ & $\mathrm{H}_{2}-\mathrm{M}_{2}$ & -1.000 \\
\hline $\begin{array}{l}\text { Moderate number of apical plasma membrane microvilli- } \\
\text { moderate electron density of secretory granules }\end{array}$ & $\mathrm{H}_{2}-\mathrm{M}_{5}$ & 1.000 \\
\hline $\begin{array}{l}\text { Moderate location density and length of apical plasma } \\
\text { membrane microvilli-large size of lysosomes }\end{array}$ & $\mathrm{H}_{5}-\mathrm{G}_{6}$ & 0.612 \\
\hline $\begin{array}{l}\text { Moderate location density and length of apical plasma mem- } \\
\text { brane microvilli- significant electron density of lysosomes }\end{array}$ & $\mathrm{H}_{5}-\mathrm{G}_{9}$ & -0.612 \\
\hline $\begin{array}{l}\text { Moderate location density and length of apical plasma mem- } \\
\text { brane microvilli-moderate number of secretory granules }\end{array}$ & $\mathrm{H}_{5}-\mathrm{M}_{2}$ & 1.000 \\
\hline $\begin{array}{l}\text { Moderate location density and length of apical plasma } \\
\text { membrane microvilli-moderate electron density of } \\
\text { secretory granules }\end{array}$ & $\mathrm{H}_{5}-\mathrm{M}_{5}$ & 1.000 \\
\hline $\begin{array}{l}\text { Moderate number of lysosomes - moderate size } \\
\text { of lysosomes }\end{array}$ & $\mathrm{G}_{2}-\mathrm{G}_{5}$ & 1.000 \\
\hline $\begin{array}{l}\text { Moderate number of lysosomes - moderate electron } \\
\text { density of lysosomes }\end{array}$ & $\mathrm{G}_{2}-\mathrm{G}_{8}$ & 0.612 \\
\hline $\begin{array}{l}\text { Moderate number of lysosomes - increased number } \\
\text { of secretory granules }\end{array}$ & $\mathrm{G}_{2}-\mathrm{M}_{3}$ & 1.000 \\
\hline $\begin{array}{l}\text { Moderate number of lysosomes - apical location } \\
\text { of secretory granules }\end{array}$ & $\mathrm{G}_{2}-\mathrm{M}_{7}$ & 1.000 \\
\hline $\begin{array}{l}\text { Moderate number of lysosomes - presence of secretory } \\
\text { granules topographic connection with lysosomes }\end{array}$ & $\mathrm{G}_{2}-\mathrm{M}_{10}$ & 1.000 \\
\hline $\begin{array}{l}\text { Moderate size of lysosomes - moderate electron density } \\
\text { of lysosomes }\end{array}$ & $\mathrm{G}_{5}-\mathrm{G}_{8}$ & 0.612 \\
\hline $\begin{array}{l}\text { Moderate size of lysosomes - increased number } \\
\text { of secretory granules }\end{array}$ & $\mathrm{G}_{5}-\mathrm{M}_{3}$ & 1.000 \\
\hline $\begin{array}{l}\text { Moderate size of lysosomes - apical location } \\
\text { of secretory granules }\end{array}$ & $\mathrm{G}_{5}-\mathrm{M}_{7}$ & 1.000 \\
\hline $\begin{array}{l}\text { Moderate size of lysosomes - presence of secretory } \\
\text { granules topographic connection with lysosomes }\end{array}$ & $\mathrm{G}_{5}-\mathrm{M}_{10}$ & 1.000 \\
\hline $\begin{array}{l}\text { Large size of lysosomes - moderate electron density } \\
\text { of lysosomes }\end{array}$ & $\mathrm{G}_{6}-\mathrm{G}_{8}$ & 0.612 \\
\hline $\begin{array}{l}\text { Large size of lysosomes-significant electron density } \\
\text { of lysosomes }\end{array}$ & $\mathrm{G}_{6}-\mathrm{G}_{9}$ & 1.000 \\
\hline $\begin{array}{l}\text { Large size of lysosomes - moderate number of secretory } \\
\text { granules }\end{array}$ & $\mathrm{G}_{6}-\mathrm{M}_{2}$ & -0.612 \\
\hline $\begin{array}{l}\text { Large size of lysosomes - moderate electron density } \\
\text { of secretory granules }\end{array}$ & $\mathrm{G}_{6}-\mathrm{M}_{5}$ & 0.612 \\
\hline $\begin{array}{l}\text { Moderate electron density of lysosomes - } \\
\text { significant electron density of lysosomes }\end{array}$ & $\mathrm{G}_{8}-\mathrm{G}_{9}$ & 0.612 \\
\hline $\begin{array}{l}\text { Moderate electron density of lysosomes- } \\
\text { increased number of secretory granules }\end{array}$ & $\mathrm{G}_{8}-\mathrm{M}_{3}$ & 0.612 \\
\hline $\begin{array}{l}\text { Moderate electron density of lysosomes - } \\
\text { apical location of secretory granules }\end{array}$ & $\mathrm{G}_{8}-\mathrm{M}_{7}$ & 0.612 \\
\hline $\begin{array}{l}\text { Moderate electron density of lysosomes - presence of topo- } \\
\text { graphic connection of secretory granules with lysosomes }\end{array}$ & $\mathrm{G}_{8}-\mathrm{M}_{10}$ & 0.612 \\
\hline $\begin{array}{l}\text { Significant electron density of lysosomes - } \\
\text { moderate number of secretory granules }\end{array}$ & $\mathrm{G}_{9}-\mathrm{M}_{2}$ & -0.612 \\
\hline $\begin{array}{l}\text { Significant electron density of lysosomes- } \\
\text { moderate electron density of secretory granules }\end{array}$ & $\mathrm{G}_{9}-\mathrm{M}_{5}$ & 0.612 \\
\hline $\begin{array}{l}\text { Moderate number of secretory granules - } \\
\text { moderate electron density of secretory granules }\end{array}$ & $\mathrm{M}_{2}-\mathrm{M}_{5}$ & -1.000 \\
\hline $\begin{array}{l}\text { Increased number of secretory granules - } \\
\text { apical location of secretory granules }\end{array}$ & $\mathrm{M}_{3}-\mathrm{M}_{7}$ & 1.000 \\
\hline $\begin{array}{l}\text { Increased number of secretory granules - presence of topo- } \\
\text { graphic connection of secretory granules with lysosomes }\end{array}$ & $\mathrm{M}_{3}-\mathrm{M}_{10}$ & 1.000 \\
\hline $\begin{array}{l}\text { Apical location of secretory granules - presence of topo- } \\
\text { graphic connection of secretory granules with lysosomes }\end{array}$ & $\mathrm{M}_{7}-\mathrm{M}_{10}$ & 1.000 \\
\hline
\end{tabular}

The traced correlations were visualized by the construction of correlation portraits (Fig. 2). 
Table 6

Correlations between the constituent elements of the secretory direction portrait of follicular thyrocytes' activity in the thyroid glands of white male rats who received $50 \mu \mathrm{g}$ of chemical nature inorganic iodine in the model conditions of iodine deficiency in the diet

\begin{tabular}{|c|c|c|}
\hline \multicolumn{2}{|c|}{ Interdependent ultrastructural elements of the portrait } & \multirow[b]{2}{*}{$\begin{array}{l}\text { Correlation } \\
\text { connection } \\
\text { (r) }\end{array}$} \\
\hline $\begin{array}{l}\text { characteristics } \\
\text { of the studied ultrastructural elements }\end{array}$ & $\begin{array}{l}\text { ultrastructural } \\
\text { elements fea- } \\
\text { tures legends }\end{array}$ & \\
\hline 1 & 2 & 3 \\
\hline $\begin{array}{l}\text { Moderate electron density of intrafollicular colloid- } \\
\text { small number of lysosomes }\end{array}$ & $\mathrm{E}_{2}-\mathrm{G}_{1}$ & 0.791 \\
\hline $\begin{array}{l}\text { Moderate electron density of intrafollicular colloid- } \\
\text { large size of lysosomes }\end{array}$ & $\mathrm{E}_{2}-\mathrm{G}_{6}$ & -0.791 \\
\hline $\begin{array}{l}\text { moderate electron density of intrafollicular colloid- } \\
\text { significant electron density of lysosomes }\end{array}$ & $\mathrm{E}_{2}-\mathrm{G}_{9}$ & 0.791 \\
\hline $\begin{array}{l}\text { Moderate electron density of intrafollicular colloid- } \\
\text { small number of secretory granules }\end{array}$ & $\mathrm{E}_{2}-\mathrm{M}_{1}$ & -0.791 \\
\hline $\begin{array}{l}\text { Moderate electron density of intrafollicular colloid- } \\
\text { moderate number of secretory granules }\end{array}$ & $\mathrm{E}_{2}-\mathrm{M}_{2}$ & 0.791 \\
\hline $\begin{array}{l}\text { Moderate electron density of intrafollicular colloid - } \\
\text { moderate electron density of secretory granules }\end{array}$ & $\mathrm{E}_{2}-\mathrm{M}_{5}$ & 0.791 \\
\hline $\begin{array}{l}\text { Moderate number of apical plasma membrane mi- } \\
\text { crovilli-moderate size of lysosomes }\end{array}$ & $\mathrm{H}_{2}-\mathrm{G}_{5}$ & 0.875 \\
\hline $\begin{array}{l}\text { Moderate number of apical plasma membrane mi- } \\
\text { crovilli-moderate electron density of lysosomes }\end{array}$ & $\mathrm{H}_{2}-\mathrm{G}_{8}$ & 1.000 \\
\hline $\begin{array}{l}\text { Moderate number of apical plasma membrane mi- } \\
\text { crovilli-apical location of secretory granules }\end{array}$ & $\mathrm{H}_{2}-\mathrm{M}_{7}$ & 1.000 \\
\hline $\begin{array}{l}\text { Significant location density and length of apical plasma } \\
\text { membrane microvilli-small number of lysosomes }\end{array}$ & $\mathrm{H}_{6}-\mathrm{G}_{1}$ & 0.791 \\
\hline $\begin{array}{l}\text { Significant location density and length of apical plasma } \\
\text { membrane microvilli-moderate size of lysosomes }\end{array}$ & $\mathrm{H}_{6}-\mathrm{G}_{5}$ & 0.845 \\
\hline $\begin{array}{l}\text { Significant location density and length of apical } \\
\text { plasma membrane microvilli-significant electron } \\
\text { density of lysosomes }\end{array}$ & $\mathrm{H}_{6}-\mathrm{G}_{9}$ & 0.791 \\
\hline $\begin{array}{l}\text { Significant location density and length of apical } \\
\text { plasma membrane microvilli-small number of } \\
\text { secretory granules }\end{array}$ & $\mathrm{H}_{6}-\mathrm{M}_{1}$ & -0.791 \\
\hline $\begin{array}{l}\text { Significant location density and length of apical } \\
\text { plasma membrane microvilli-moderate number of } \\
\text { secretory granules }\end{array}$ & $\mathrm{H}_{6}-\mathrm{M}_{2}$ & 0.791 \\
\hline $\begin{array}{l}\text { Significant location density and length of apical } \\
\text { plasma membrane microvilli-moderate electron } \\
\text { density of secretory granules }\end{array}$ & $\mathrm{H}_{6}-\mathrm{M}_{5}$ & 0.791 \\
\hline $\begin{array}{l}\text { Significant location density and length of apical } \\
\text { plasma membrane microvilli-presence of secretory } \\
\text { granules topographic connection with lysosomes }\end{array}$ & $\mathrm{H}_{6}-\mathrm{M}_{10}$ & -0.791 \\
\hline
\end{tabular}

\begin{tabular}{|c|c|c|}
\hline 1 & 2 & 3 \\
\hline $\begin{array}{l}\text { Small number of lysosomes- } \\
\text { large size of lysosomes }\end{array}$ & $\mathrm{G}_{1}-\mathrm{G}_{6}$ & -0.881 \\
\hline $\begin{array}{l}\text { Small number of lysosomes - } \\
\text { significant electron density of lysosomes }\end{array}$ & $\mathrm{G}_{1}-\mathrm{G}_{9}$ & 0.875 \\
\hline $\begin{array}{l}\text { Small number of lysosomes- } \\
\text { small number of secretory granules }\end{array}$ & $\mathrm{G}_{1}-\mathrm{M}_{1}$ & -0.881 \\
\hline $\begin{array}{l}\text { Small number of lysosomes - } \\
\text { moderate number of secretory granules }\end{array}$ & $\mathrm{G}_{1}-\mathrm{M}_{2}$ & 0.875 \\
\hline $\begin{array}{l}\text { Small number of lysosomes - } \\
\text { moderate electron density of secretory granules }\end{array}$ & $\mathrm{G}_{1}-\mathrm{M}_{5}$ & 0.875 \\
\hline $\begin{array}{l}\text { Moderate number of lysosomes - } \\
\text { moderate size of lysosomes }\end{array}$ & $\mathrm{G}_{2}-\mathrm{G}_{5}$ & -0.764 \\
\hline $\begin{array}{l}\text { Moderate number of lysosomes- } \\
\text { presence of topographic connection } \\
\text { of secretory granules with lysosomes }\end{array}$ & $\mathrm{G}_{2}-\mathrm{M}_{10}$ & -0.921 \\
\hline $\begin{array}{l}\text { Significant number of lysosomes - } \\
\text { moderate size of lysosomes }\end{array}$ & $\mathrm{G}_{3}-\mathrm{G}_{5}$ & -0.854 \\
\hline $\begin{array}{l}\text { Significant number of lysosomes- } \\
\text { presence of topographic connection } \\
\text { of secretory granules with lysosomes }\end{array}$ & $\mathrm{G}_{3}-\mathrm{M}_{10}$ & 0.791 \\
\hline $\begin{array}{l}\text { Moderate size of lysosomes - } \\
\text { moderate electron density of lysosomes }\end{array}$ & $\mathrm{G}_{5}-\mathrm{G}_{8}$ & 0.873 \\
\hline $\begin{array}{l}\text { Moderate size of lysosomes - } \\
\text { apical location of secretory granules }\end{array}$ & $\mathrm{G}_{5}-\mathrm{M}_{7}$ & 0.873 \\
\hline $\begin{array}{l}\text { Moderate size of lysosomes - presence of topographic } \\
\text { connection of secretory granules with lysosomes }\end{array}$ & $\mathrm{G}_{5}-\mathrm{M}_{10}$ & -0.871 \\
\hline $\begin{array}{l}\text { Large size of lysosomes - } \\
\text { significant electron density of lysosomes }\end{array}$ & $\mathrm{G}_{6}-\mathrm{G}_{9}$ & -1.000 \\
\hline $\begin{array}{l}\text { Large size of lysosomes - } \\
\text { small number of secretory granules }\end{array}$ & $\mathrm{G}_{6}-\mathrm{M}_{1}$ & 1.000 \\
\hline $\begin{array}{l}\text { Large size of lysosomes - } \\
\text { moderate number of secretory granules }\end{array}$ & $\mathrm{G}_{6}-\mathrm{M}_{2}$ & -1.000 \\
\hline $\begin{array}{l}\text { Large size of lysosomes- } \\
\text { moderate electron density of secretory granules }\end{array}$ & $\mathrm{G}_{6}-\mathrm{M}_{5}$ & -1.000 \\
\hline $\begin{array}{l}\text { Moderate electron density of lysosomes - } \\
\text { apical location of secretory granules }\end{array}$ & $\mathrm{G}_{8}-\mathrm{M}_{7}$ & 1.000 \\
\hline $\begin{array}{l}\text { Significant electron density of lysosomes - } \\
\text { small number of secretory granules }\end{array}$ & $\mathrm{G}_{9}-\mathrm{M}_{1}$ & -1.000 \\
\hline $\begin{array}{l}\text { Significant electron density of lysosomes - } \\
\text { moderate number of secretory granules }\end{array}$ & $\mathrm{G}_{9}-\mathrm{M}_{2}$ & 1.000 \\
\hline $\begin{array}{l}\text { Significant electron density of lysosomes - } \\
\text { moderate electron density of secretory granules }\end{array}$ & $\mathrm{G}_{9}-\mathrm{M}_{5}$ & 1.000 \\
\hline $\begin{array}{l}\text { Small number of secretory granules - } \\
\text { moderate number of secretory granules }\end{array}$ & $\mathrm{M}_{1}-\mathrm{M}_{2}$ & -1.000 \\
\hline $\begin{array}{l}\text { Small number of secretory granules - } \\
\text { moderate electron density of secretory granules }\end{array}$ & $\mathrm{M}_{1}-\mathrm{M}_{5}$ & -1.000 \\
\hline $\begin{array}{l}\text { Moderate number of secretory granules - } \\
\text { moderate electron density of secretory granules }\end{array}$ & $\mathrm{M}_{2}-\mathrm{M}_{5}$ & 1.000 \\
\hline
\end{tabular}

$b$
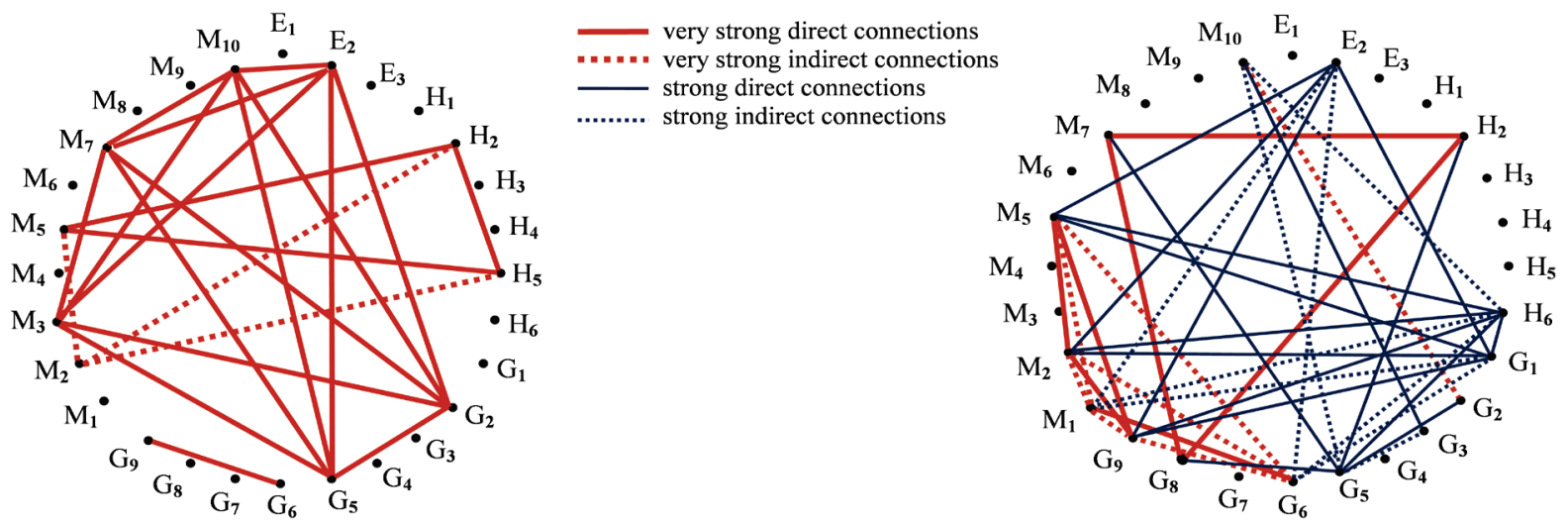

Fig. 2. Graphic representation of the structure of the secretory direction correlation portraits of follicular thyrocyte activity in the thyroid glands of white male rats that received $50 \mu \mathrm{g}$ of organic $(a)$ and inorganic $(b)$ iodine of chemical nature under the model conditions of iodine deficiency in the diet

\section{Discussion}

An analytical review of scientific literature on the use of a mathematical apparatus for the needs of biomedical diagnostics has confirmed the need for the development and implementation of new approaches to the objectivization of non-numerical information. It has been determined that the object of research in biomedical diagnostics is objective data, which are mainly numerical (quantitative).

Non-numerical (qualitative and binary) data due to the low adaptability of the mathematical support for working with such information are 
usually not objectivized, which makes it little accessible for study and reduces their significance for evidence-based diagnostics. Thus, most of the mathematical analysis methods that are currently used in biology and medicine cannot provide a complete comprehensive description and an indepth study of cell activity at the submicroscopic level of their structure.

At the same time, nowadays in medical-biological research the question of the quality of diagnosis is thrown into sharp relief (Avtandilov, 2002). One of the ways to achieve this is the intellectual analysis of data, which is an interdisciplinary research field combining modern achievements in many fields of mathematics (Feng et al., 2014). This approach is quite promising as it gives an opportunity to increase the accuracy of the diagnostic process by deepening the researcher's mindset. The main instrument of intellectual data analysis is the combination of correlation analysis, cluster analysis and evolution analysis. The approach we used to transform the qualitative and binary data obtained in characterizing cells lies in the sequential application of certain elements of the definite mathematical analysis tools. This permits one to determine differences in the morphological status of ultrastructural implementers of the studied fields of the hormone-producing cells' activity, as well as to study the interrelations and interdependence between them.

The study of the nomenclature, strength, and direction of correlation connections traced between the protein-synthesizing ultrastructures showed that when organic iodine was administered, the functional state of both the rough ER and the Golgi apparatus was in equilibrium. This was indicated by very strong connections between the moderately expressed dimensions of their substructures $(r=1.000)$; the connections between other ultrastructures were realized through the free and membrane bound ribosomes, the number of which was moderate or significant. The analysis of the general picture of connections between the ultrastructure of the discussed portrait allowed us to determine that synthetic activity of the thyrocytes was intense and functionally balanced. With consumption of inorganic iodine, the main load in the synthesis of the hormone protein part fell on the extended substructures of the Golgi apparatus and on moderately expressed substructures of the rough $\mathrm{ER}(\mathrm{r}=1.000)$.

Dissociation between the degrees of functional activity of the Golgi apparatus substructures, which were moderately expressed, and the rough ER, which were expanded $(r=0.791)$, and between the moderate amount of bound ribosome located on the reticulum membrane and the reduced amount of free ribosomes, located in the thyrocyte cytoplasm $(r=1.000)$ were determined. The above indicates that when inorganic iodine of a chemical nature was received, the hormone-producing activity of the follicular thyrocyte was accompanied by a certain functional tension.

Analysis of the correlation connection features, traced between organelles-implementers of the secretory direction in the follicular thyrocytes' activity, showed that consuming organic iodine contributed to the harmonic secretion, as evidenced by the uniform involvement of almost all cluster elements, which were expressed moderately, in the portrait. The largest aggregates of correlation connections were $\mathrm{E}_{2}, \mathrm{H}_{2}, \mathrm{H}_{5}, \mathrm{G}_{2}$, $\mathrm{G}_{5}, \mathrm{M}_{3}, \mathrm{M}_{7}$, and $\mathrm{M}_{10}$, indicating the conditions favourable enough for release of the produced hormone. Despite this, the portrait also pointed out that the secretion took place with some strain, as evidenced by very strong indirect connections, with a moderate amount of secretory granules, moderate number and moderate length of apical microvilli and a moderate electronic density of secretory granules $(\mathrm{r}=-1.000)$.

Meanwhile, when consuming a similar dose of inorganic iodine, the existence of complications in the secretion process was indicated by the dissociation of connections $(r=1.000)$ between a significant degree of the lysosomes' electron density and moderate amount of secretory granules having moderate electron density and uneven involvement in the portrait of its components; the main functional load of the hormone release devolved upon lysosomes and secretory granules. The existence of conditions favourable for release of the hormonal product was evidenced by connections between moderate amounts of apical microvilli with moderate amounts of lysosomes $(r=0.875)$ and apical localization of secretory granules $(r=1.000)$.

Consequently, the general picture of correlation portraits, the nomenclature of organelles, as well as the strength and direction of the correlations, traced between the components of the portrait, were determined by the chemical nature of iodine used as a substrate for thyroid hormones. Thus, in the study of the processes of synthesis of hormones with the organic iodine consumption, the predominant ultrastructure elements of the portrait were the substructures of the rough ER and the Golgi apparatus, the moderate expression of which $\left(\mathrm{J}_{2}\right.$ and $\left.\mathrm{K}_{2}\right)$ indicated a balanced functional state of the follicular thyrocytes. By contrast, consumption of inorganic iodine was accompanied by an increase in the number of ultrastructures in the studied cluster, involved in the process of hormone synthesis and the connections between substructures of different functional activity $\left(\mathrm{J}_{4}, \mathrm{~K}_{1}, \mathrm{~L}_{3}\right)$, indicating functional imbalance and strain in synthetic activity.

The observed tendency maintained in the study of the hormonal product secretion. Thus, under the influence of inorganic iodine, the number of nodal points (places of correlation aggregates in the portrait) and their filling with correlation connections were greater than at the consumption of organic iodine. This requires a more in-depth study, since it may have opposite interpretations: indicate the need to increase the constituents to ensure the system's stability over functioning or, conversely, be a sign of the uniform involvement of the cluster's constituents in the secretion processes which is the best for the hormonal product release. We are more inclined to the first option, since the presence of dissociation has been determined in the state of cluster organelles, which are functionally important for the hormone secretion process. In particular, the size and electronic density of lysosomes that played a prominent role in secretion were quite significant $\left(\mathrm{G}_{6}, \mathrm{G}_{9}\right)$, while the topographic connection between lysosomes and secretory granules (M10), which is a prerequisite for the hormone release, was not always clear. Thus, the comparison of the action of organic and inorganic iodine showed that in the model conditions of iodine deficiency, consumption of organic iodine contributes to a greater activation of hormonal synthesis in the follicular thyrocytes, whereas under the influence of inorganic iodine secretion of the produced hormone is somewhat complicated.

The obtained results allow us to deepen the study of specific activity mechanisms of hormone-producing cells and correspond to the views of Mintser et al. (2003) about the importance of the mutual activity of all components in the morpho-functional module, aimed at achieving a general beneficial result. The use of non-numerical information in biometrics (Takeda et al., 2011), medical expert systems (Korenevskiy, 2015), medicine (Adlassnig, 2016), and studies of the cell as a biological object are to some extent consistent with the views of Goiko \& Mokhnachov (2013) and Das et al. (2016) on the importance of applying mathematical approaches, in particular, step-by-step algorithms designed to enhance informative value in the analysis of diverse biomedical information. The practical use of correlation analysis in cytology permits us to significantly expand the scope of cell studies, in particular, to deepen the study of hormonopoiesis mechanisms.

\section{Conclusion}

The use of correlation analysis for research on hormone producing cells allows one to deepen the understanding of the features of intimate mechanisms in different aspects of their activity, which substantially expands the research platform and increases cognitive potential. The presented approach to the transformation of non-numerical information about the morphofunctional state of hormone-producing cells into numerical data permits one to determine, study, analyze and generalize the peculiarities of the changes in both the individual ultrastructures and their functional complexes (clusters) in response to the actions of various factors and to trace the interdependence and interactions existing between them. Taking into account the convenience of use, the presented approach to transforming qualitative data on the state of a cell into quantitative indices becomes an important source for obtaining objective information in cytophysiology and cytomorphology.

The prospects for further research lie in the in-depth study of the energy and transport aspects in the activity of hormone-producing cells at the ultrastructure level of their organization. 


\section{References}

Adlassnig, K.-P. (2016). Fuzzy methods in clinical research and patient care. 12th International Conference on Application of Fuzzy Systems and Soft Computing (ICAFS). Vienna, Austria, 2016. Procedia Computer Science, 102, 9-11.

Aguilera, P. A., Fernandez, A., Fernandez, R., Rumi, R., \& Salmeron, A. (2011). Bayesian networks in environmental modelling. Environmental Modelling and Software, 26(12), 1376-1388.

Akoglu, H. (2018). User's guide to correlation coefficients. Turkish Journal of Emergency Medicine, 18(3), 91-93.

Amigó, J. M., \& Small, M. (2017). Mathematical methods in medicine: Neuroscience, cardiology and pathology. Philosophical Transactions. Series A, Mathematical, Physical, and Engineering Sciences, 375, 2096.

Avtandilov, G. G. (2002). Osnovy kolichestvennoy patologicheskoy anatomii [Basis of quantitative pathological anatomy]. Meditsina, Moscow (in Russian).

Barrett, E. J. (2016). The thyroid gland. In: Boron, W. F., \& Boulpaep, E. L. (Eds.) Medical physiology. 3rd ed. Ch. 49. Elsevier, Philadelphia. Pp. 1006-1017.

Batushansky, A., Toubiana, D., \& Fait, A. (2016). Correlation-based network generation, visualization, and analysis as a powerful tool in biological studies: A case study in cancer cell metabolism. BioMed Research International, 2016, 9 .

Bessmertnyy, I. A., Nugumanova, A. B., \& Platonov, A. B. (2019). Osnovy logicheskogo programmirovaniya [Fundamentals of logical programming]. In: Intellektual'nyye sistemy [Intellectual systems]. Yurayt, Moscow. P. 31 (in Russian).

Bewick, V., Cheek, L., \& Ball, J. (2003). Statistics review 7: Correlation and regression. Critical Care, 7(6), 451-459.

Caplan, M. J. (2016). Functional organization of the cell. In: Boron, W. F., \& Boulpaep, E. L. (Eds.). Medical Physiology. 3rd ed. Ch. 2. Elsevier, Philadelphia. Pp. 8- 46.

Courvoisier, D. S., Combescure, C., Agoritsas, T., Gayet-Ageron, A., \& Perneger, T. V. (2011). Performance of logistic regression modeling: Beyond the number of events per variable, the role of data structure. Journal of Clinical Epidemiology, 64(9), 993-1000.

Das, S., Guha, D., \& Dutta, B. (2016). Medical diagnosis with the aid of using fuzzy logic and intuitionistic fuzzy logic. Applied Intelligence, 45(3), 850-867.

Dev, U., Sultana, A., Saha, D., \& Mitra, N. (2015). Application of fuzzy logic in medical data interpretation. Bangladesh Journal of Scientific and Industrial Research, 49(3), 137-146.

Feng, Y., Wang, Y., Guo, F., \& Xu, H. (2014). Applications of data mining methods in the integrative medical studies of coronary heart disease: Progress and prospect. Evidence-Based Complementary and Alternative Medicine, 2014, 791841 .

Goiko, O. V., \& Mokhnachov, S. I. (2013). Tekhnolohiya obrobky i analizu medychnykh danykh $\mathrm{z}$ urakhuvannyam yikh osoblyvostey [Technology of processing and analysis of medical data in view of their features]. Zaporozhye Medical Journal, 76(1), 82-83 (in Ukrainian).

Gupta, M. M. (2011). Forty-five years of fuzzy sets and fuzzy logic - A tribute to professor Lotfi A. Zadeh (the father of fuzzy logic). Scientia Iranica, 18(3), 685-690.

Gürsel, G. (2016). Healthcare, uncertainty, and fuzzy logic. Digital Medicine, 2(3), 101-112.

Kim, N., Fischer, A. H., Dyring-Andersen, B., Rosner, B., \& Okoye, G. A. (2017) Research techniques made simple: Choosing appropriate statistical methods for clinical research. Journal of Investigative Dermatology, 137(10), e173-e178.

Korenevskiy, N. A. (2015). Application of fuzzy logic for decision-making in medical expert systems. Biomedical Engineering, 49(1), 46-49.

$\mathrm{Lu}, \mathrm{K}$. (2016). On logistic regression analysis of dichotomized responses. Pharmaceutical Statistics, 16(1), 55-63.

Maranzatto, C. F., Miot, H. A., Miot, L. D., \& Meneguin, S. (2016). Psychometrican analysis and dimensional structure of the Brazilian version of melasma quality of life scale (MELASQoL-BP). Anais Brasileiros de Dermatologia, 91(4), 422-428.

Meeus, W., van de Schoot, R., Keijsers, L., Schwartz, S. J, \& Branje, S. (2010). On the progression and stability of adolescent identity formation. A fivewave longitudinal study in early-to-middle and middle-to-late adolescence. Child Development, 81(5), 1565-1581.
Mintser, O. P., Voronenko, Y. V., \& Vlasov, V. V. (2003). Obroblennya klinichnykh i eksperymental'nykh danykh u medytsyni [Processing of clinical and experimental data in medicine]. Vishcha Shkola, Kyiv (in Ukrainian).

Miot, H. A. (2017). Assessing normality of data in clinical and experimental trials. Jornal Vascular Brasileiro, 16(2), 88-91.

Miot, H. A. (2018). Correlation analysis in clinical and experimental studies. Jornal Vascular Brasileiro, 17(4), 275-279.

Murray, J. D. (2003). Mathematical biology II: Spatial models and biomedical applications (interdisciplinary applied mathematics). 3rd ed. Vol. 18. Springer, New York.

Mutwil, M., Usadel, B., Schütte, M., Loraine, A., Ebenhöh, O., \& Persson, S. (2010). Assembly of an interactive correlation network for the Arabidopsis genome using a novel heuristic clustering algorithm. Plant Physiology, 152(1), 2943.

Patel, A., Gupta, S. K., Rehman, Q., \& Verma, M. K. (2013). Application of fuzzy logic in biomedical informatics. Journal of Emerging Trends in Computing and Information Sciences, 4(1), 57-62.

Plashchevaya, E. V., Smirnov, V. A., Nigei, N. V., \& Lysak, V. A. (2014). Osnovnyye vidy vrachebnoy logiki [The main types of medical logic]. In: Posobiye dlya prakticheskikh zanyatiy po meditsinskoy informatike [Textbook for practical training in medical informatics]. Amur State Medical Academy, Blagoveshchensk. P. 176 (in Russian)

Rietbergen, C., Klugkist, I., Janssen, K. J., Moons, K. G., \& Hoijtink, H. (2011) Incorporation of historical data in the analysis of randomized therapeutic trials. Contemporary Clinical Trials, 32(6), 848-855.

Rossi, F. H., Volpato, M. G., Metzger, P. B., Beteli, C. B., de Almeida, B. L., Rossi, C. B., \& Izukawa, N. M. (2015). Relationships between severity of signs and symptoms and quality of life in patients with chronic venous disease. Jornal Vascular Brasileiro, 14(1), 22-28.

Ryabukha, O. I. (2018a). Perspectives of applying new approaches to the implementation of mathematical technologies in the study of cell activity. Medical Informatics and Engineering, 1, 67-75 (in Ukrainian).

Ryabukha, O. I. (2018b). Search for markers of changes of the synthetic activity of thyrocyte under the influence of iodine reception in iodine deficiency conditions. World of Medicine and Biology, 65, 179-185.

Ryabukha, O. I. (2019). Application of mathematical approaches in medicine on the example of follicular thyrocytes secretory activity study. World of Medicine and Biology, 67, 181-187.

Ryabukha, O., \& Dronyuk, I. (2018). The portraits creating method by correlation analysis of hormone-producing cells data. 1st International Workshop on Informatics and Data-Driven Medicine (IDDM). Lviv, Ukraine. Pp. 135-145.

Schober, P., Boer, C., \& Schwarte, L. A. (2018). Correlation coefficients: Appropriate use and interpretation. Anesthesia and Analgesia, 126(5), 1763-1768.

Takeda, T., Kuramoto, K., Kobashi, S., \& Hata, Y. (2011). Fuzzy-logic is precise its application to biometric system. Scientia Iranica, 18(3), 655-662.

Talbot, P. (2018). Spacetime programming: A synchronous language for constraint search. Sorbonne University, Pierre and Marie Curie University, Paris. Pp. 57-58.

Tighe, M., Pollino, C. A., \& Wilson, S. C. (2013). Bayesian networks as a screening tool for exposure assessment. Journal of Environmental Management, $123,68-76$.

Tiwari, M. (2012). A mathematical applications into the cells. Journal of Natural Science, Biology and Medicine, 3(1), 19-23.

Torres, A., \& Nieto, J. J. (2006). Fuzzy logic in medicine and bioinformatics. Journal of Biomedicine and Biotechnology, 2006, 91908 .

Uurtio, V., Monteiro, J. M., Kandola, J., Shawe-Taylor, J., Fernandez-Reyes, D., \& Rousu, J. (2018). A tutorial on canonical correlation methods. ACM Computing Surveys, 50(6), 95.

van de Schoot, R., Kaplan, D., Denissen, J., Asendorpf, J. B., Neyer, F. J., \& van Aken, M. A. (2014). A gentle introduction to Bayesian analysis: Applications to developmental research. Child Development, 85(3), 842-860.

van Someren, E. P., Vaes, B. L., Steegenga, W. T., Sijbers, A. M., Dechering, K. J. \& Reinders, M. J. (2006). Least absolute regression network analysis of the murine osteoblast differentiation network. Bioinformatics, 22(4), 477-484.

Whitley, E., \& Ball, J. (2002). Statistics review 1: Presenting and summarising data. Critical Care, 6(1), 66-71.

Yadav, S. (2018). Correlation analysis in biological studies. Journal of the Practice of Cardiovascular Sciences, 4(2), 116-121. 